\title{
ERROR ANALYSIS OF INDONESIAN STUDENTS IN LEARNING TIME ASPECT " 着 ZHE" AT NANCHANG UNIVERSITY IN CHINA
}

\author{
Elvira Septevany ${ }^{1}$, Liu Dandan ${ }^{2} \&$ Ria Riski Marsuki ${ }^{3}$ \\ ${ }^{I}$ Tourism Department, Politeknik Negeri Bali \\ ${ }^{2}$ Study Program of Linguistik, Program Doktor, Universitas Udayana \\ ${ }^{3}$ Faculty of Language and Arts, Universitas Negeri Semarang
}

Corresponding Author: Elvira Septevany E-mail: elvira_s@pnb.ac.id

\begin{tabular}{l}
\hline ARTICLE INFO \\
Received: 30-06-2020 \\
Accepted: 03-10-2020 \\
Published: 12-102020 \\
Volume: 4 \\
Issue: 2 \\
DOI: \\
https://doi.org/10.33019/lire.v \\
3i2.83 \\
\hline KEYWORDS \\
\hline
\end{tabular}
ABSTRACT

time aspect “着he”,

Indonesian students, 4 type

errors, strategy teaching

method

For foreign students, Mandarin time aspect “着zhe" is a common and relatively difficult grammar point to grasp. The research method is a quantitative method and a qualitative descriptive method to describe, identify the types of errors made by Indonesian learners in learning time aspect “着zhe". The type of errors are misordering, misuse, omission, and added. Data collection technique used is purposive sampling, i.e. Mandarin language learners at the University of Nanchang, China, which had received writing, grammar and structure, and syntax courses. This question is taken in accordance with the usual sentence forms used in everyday life. The purpose of this technique is to obtain relevant data in order to solve the problem of learning Mandarin, especially regarding the time aspect " 着 zhe". The results of relevant questionnaire show that Indonesian students lack of basic knowledge of time aspect and they did not understand or forget the rules of time aspect. So, they use Indonesian grammar to answer Mandarin time aspect “着 zhe" questionnaire. This is indicated by the results of the questionnaire given, there are 3 forms of performance errors above $50 \%$, i.e. misuse error has $65 \%$, misordering error has $60 \%$, added error has $55 \%$ and there is 1 form error below $50 \%$ namely omission error, has $45 \%$. The Conclusions of time aspect Mandarin "着 zhe" is a form of Mandarin grammar that is often used. This time aspect "着 zhe" has several rules in matching with other words. To understand this, Indonesian students need to learn step by step and perseverance in study and practice, so they can understand the uses of time aspect “着 zhe”.

\section{INTRODUCTION}

Morphologically, Mandarin and Indonesian come from different language groups. Mandarin is an isolative language, while Indonesian is an agglutinative language. Isolative language type, that is, the type of language which expresses grammatical relationships and is dependent on word order, while the word form does not change morphologically but the changes are only due to differences in tone. This type of language is also called the Tonis language. Agglutinative language type, namely the type of language whose grammatical relationships and word structure are expressed by a combination of language elements freely. In this type, word formation can be done by affixation

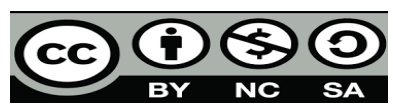

This work is licensed under Creative Commons Attribution-ShareAlike 4.0 Internasional. Copyright @ 2020, Elvira Septevany, Liu Dandan \& Ria Riski Marsuki 
(word formation through affixing), composition (word formation through compounding), and reduplication (word formation through repetition). When viewed from the morphology, the grammatical relationship and word structure of the two languages are indeed very different. That is, Mandarin already has a sequence of words to arrange into one sentence while Indonesian is a more free language. For example time aspect “着zhe” when put together with an acronym word, it must be inserted between the two acronyms, while in Indonesian, there is no form of acronym like this. So, this causes errors in using time aspect “着 zhe” by Indonesian students. Another example is time aspect "sedang" in Indonesian when it involves two verbs while using one time aspect is "sedang" with another word "sambil". For example, "Sister is dancing while singing". Whereas in Mandarin, it cannot add time aspect “着zhe”. This will cause an error in applying and using the rules of time aspect “着 zhe”. The previous researchers, as describe briefly in literature review below, have discussed the whole aspect of time, namely “着zhe”, “了le” dan “过guo” and using objects from other countries. For the foreigner students, Mandarin time aspects are usually seen as grammar and also a little bit difficult to master it.

Our research shows that Indonesian students seem lack of understanding about this topic that lead to mistake when they used it. This research really needs to be analyze because time aspect “ 着zhe" is always used in daily conversation and every Chinese book discusses this principle but at different levels. Furthermore, this error will causes into a misunderstanding of communication with Mandarin native speakers. Based on this problem, the author would like to analyze Indonesian students error in using Mandarin time aspect “着zhe” and what causing these errors, and at last consider the effective teaching method to solve these problems. Based on the literature review below, as long as the author's knowledge, it can be said that these problems has never been studied in existing linguistic journals.

\section{LITERATURE REVIEW}

Mandarin is an isolative language, a language whose words are formed from a single morpheme. While Indonesian is an agglutinative language that tends to experience morpheme changes when combined with other words, so it is difficult to segment (Yi Ying, 2011). The main functions of

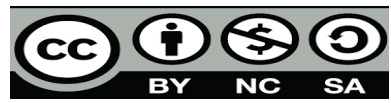


grammatical Mandarin and Indonesian are function as time aspect. July Dianita Tarigan (2016) believes that main difference between time aspect in Mandarin and Indonesian lies in the combination of words and verbs. In Mandarin, time aspects are placed after the verb, while in Indonesian, time aspects are placed before the verb. Time aspects “着 zhe”, “了 le” and “过 guo” all have characteristics of their respective meanings. After time aspects are paired with verbs, the word will experience a change in meaning (房玉清, 1992). 穆颖 (2001) said that the time aspect “了 le" placed behind the verb means something that has been completed, time aspect “过 guo" placed behind the verb means work or an action that has already taken place, and time aspect “着 zhe" placed behind the verb indicates that the activity or work is in progress.

Rika Ariandini Hutasoit (2012) divides these Mandarin time aspects into three categories: “ 助词auxiliary structure”, “语气 auxiliary mood” and “时 态 auxiliary verb”. Researcher analyzes the use of aspect aspects “了 le" and “过 guo" in Chinese sentences. Generally, students usually make errors using aspects of the particle of Mandarin as well. Students don't understand when and where to use both words. The similarities of “了le" and “过guo" are used after verb and adjective. The difference of “了 le" and “过 guo" is in tense. Aspect particle “了 le" used in past, present, and future. Meanwhile aspect particle “过 guo" is only used in past.

In the process of learning time aspects in Mandarin, Chen argues that errors in the use of aspect words in sentences occur at moderate and high levels (陈德铭, 2012). Another case with Liu, he said that native speakers of Indonesian learners in learning time aspects could understand about the placement of the three time aspects quite well. However, for three time aspects, the time aspect “了 le" is the most difficult aspect for Indonesian students to understand (刘催勤, 2006). Viewed from a modern Chinese perspective and teaching Chinese as a foreign language, he studies the practice of the dynamic “着zhe” for Indonesian, Thai and Korean students. The results found that foreign students from various countries have different characteristics when they learn Mandarin. The most difficult thing for Indonesian and Korean students to master is time aspect “ 着 zhe” (吕圆, 2012). 
Mansur Akil (2009) explains about English-Indonesian translators often finding difficulties in translating English verbs. This is due to their lack of understanding of the concept of time aspect, adverb of time in both English and Indonesian, and tenses in English. While to translate tenses and time aspects can be done by using particles like: "masih", "sedang", "sudah/telah" and adverbs of time such as "kemarin", "tadi", "besok", "lusa" and "minggu depan". Errors in learning a second language or foreign language are caused by two factors, namely interlingual errors and intralingual errors. Interlingual errors are caused by the interpretation or application of the rules of mother tongue into the second language learned by the learner. Whereas intralingual errors are caused by a lack of mastery of the learner of the second language learned (Dian Indihadi).

\section{METHODOLOGY}

The research method used is a quantitative method and a qualitative descriptive method to describe, identify the types of errors made by Indonesian learners in learning time aspect “着zhe”. The type of errors are misordering, misuse, omission, and added. Data collection technique used is purposive sampling, i.e. Mandarin language learners at the University of Nanchang, China, which had received writing, grammar and structure, and syntax courses. This question is taken in accordance with the usual sentence forms used in everyday life. The author distributes questionnaires to 20 students. Then the writer processes the data based on Mandarin time aspect “ 着zhe” based on the book 陆俭明 (2011) and Dian Indihadi, that shows the type of errors generally made by foreign language students. Table 1 shows four type of errors and questions form. The purpose of this technique is to obtain relevant data in order to solve the problem of learning Mandarin, especially regarding the time aspect “着 zhe”. 
Table 1. Four type of errors and questions form

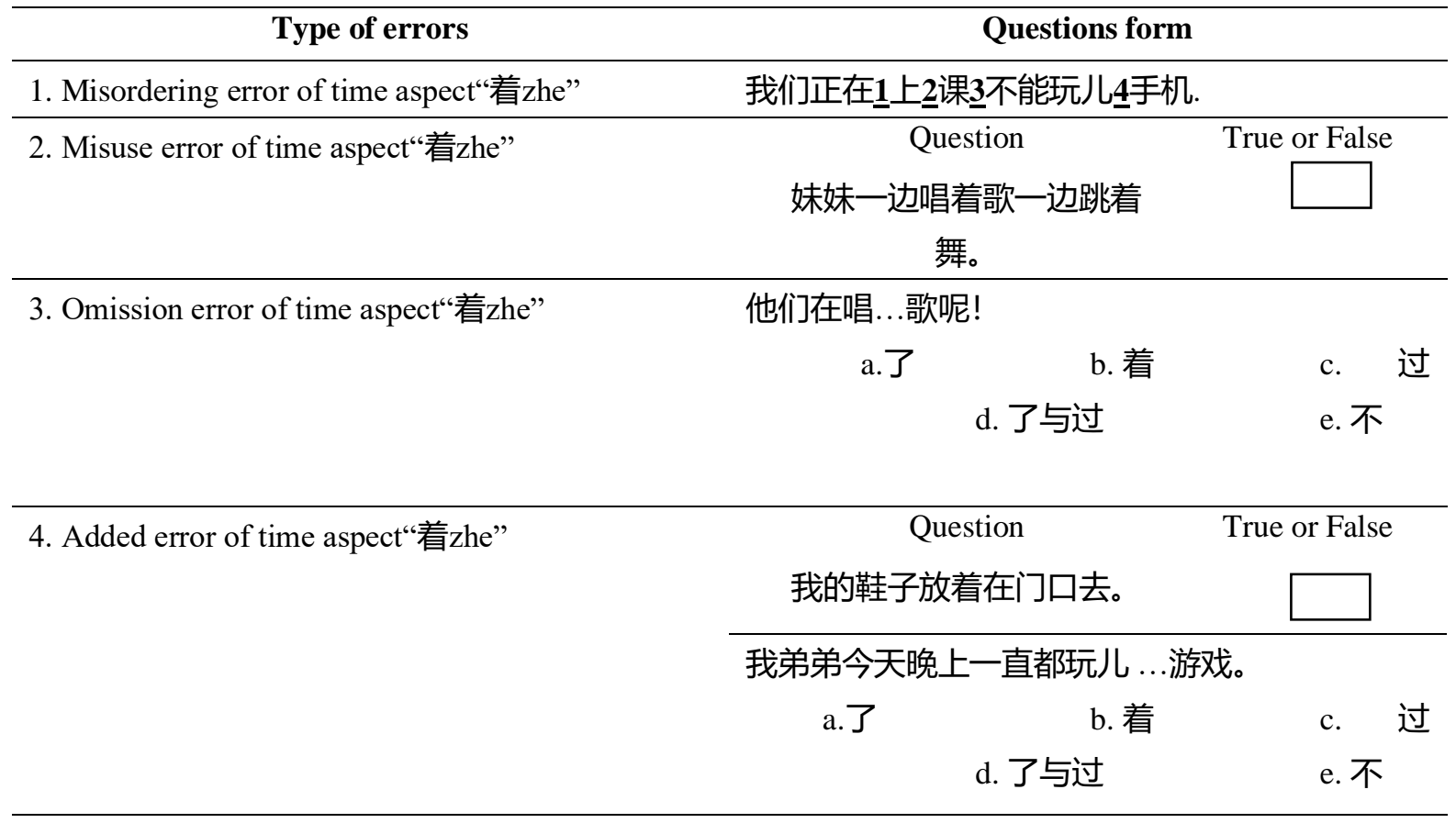

\section{RESULTS AND DISCUSSION}

Based on the survey of 20 Indonesian students that studying Mandarin in Nanchang University, the author makes a detailed analysis of the errors of Indonesian students in the process of learning Mandarin time aspect “着zhe”. There are 3 types of mistakes that always occur when foreign learn Mandarin, namely misordering, misuse, and omission ( 陆俭明, 2011). But according to Dian Indihadi, when viewed in terms of performance strategies, there are 4 types of errors namely misordering, misuse, addition and omission. The four types of errors in the formation strategy category were made by native speakers of Indonesian learners who were and had learned time aspect “着 zhe" in Mandarin. The following are the formation mistakes that often made by Indonesian students. 


\section{Misordering error of time aspect“着zhe”}

Misordering error is misplacement and use location error. In Figure 1 shows the existence of time aspect “着zhe” placement error. This problem requires students to insert time aspect “着zhe” in the part of the sentence that has been numbered correctly.

\section{我们正在 1 上 $\underline{2}$ 课 $\underline{3}$ 不能玩儿 $\underline{4}$ 手机.}

Figure 1. Type question of misordering error of time aspect“着zhe”

From 20 students, there are 12 students make misodering to this sentence. From 20 students there were 12 students who inserted time aspect “着zhe” in number 4. Because “玩儿 wanr” and “手机 shouji” are verbs and nouns but they are not acronyms. The correct placement of time aspect “着 zhe” is in number 2 between the words “上 shang” and “课 ke”. Misplacement and use location error happen it because of the influence of the mother tongue, it leads to misplacement in the process of using “着zhe”. Sentence (1) below, is the correct time aspect placement “着 zhe”.

（1）我们正在上着课不能玩儿手机。We are studying and forbidden to play mobile phones.

\begin{tabular}{|c|c|c|c|c|c|}
\hline 我们 & 正在 & 上着课 & 不能 & 玩儿 & 手机 \\
\hline kami & saat ini & sedang belajar & tidak boleh & bermain & handphone \\
\hline
\end{tabular}

“上着课 shangzheke” is acronym so the time aspect “着 zhe” needs to be placed between the acronym i.e. between the words “上 shang” and “课 ke”. Many Indonesian students put “着 zhe” between the words “玩儿 wanr” and “手机 shouji”. Indonesian students actually understand the rules of using acronym, that if acronym meets with time aspect “着 zhe”, it must be placed between the word acronym. But the placement of the word is wrong. They think “玩儿 手机 wanr shouji" is the word of acronym, but it's not. So, this is misordering error, which is causes by lack of understanding of what words are included in the word acronym.

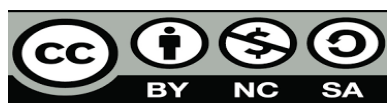




\section{Misuse error of time aspect“着zhe”}

Misuse error is wrong use of the wrong rule, it should not use time aspect “着 zhe” but they using the time aspect “着 zhe” in sentences. Sentence (2) shows examples of sentences that are incorrect using the rules of time aspect “着zhe”.

(2) *妹妹一边唱着歌一边跳着舞。*Sister is dancing while singing.

\begin{tabular}{ccccc}
\hline Adik perempuan & sedang & bernyanyi & sambil & menari. \\
\hline 妹妹 & 着 & 唱歌 & 一边 & 跳舞 \\
& & & & \\
\hline
\end{tabular}

The sentence (2) above, is an example of a wrong sentence. The word conjunction “一边... 一边yibian ... yibian" in Mandarin cannot match with time aspect “着zhe” because the conjunction “一边... 一边yibian ... yibian” is a fixed form in grammar. It indicates that the verb in the sentence is happening and is ongoing so that it cannot match again with time aspect “着zhe”, because it has the same meaning. Whereas in Indonesian, time aspect “着zhe” must match with the conjunction “一边yibian” to indicate the two activities that are taking place together. The following forms of true or false questions done by the student, shown in Figure 2.

\begin{tabular}{|cc|}
\hline Question & True or False \\
妹妹一边唱着歌一边跳着舞。 \\
\hline
\end{tabular}

Figure 2. Type question of misuse error of time aspect“着zhe”

The sentence above shows that almost all Indonesian students answer that sentence is correct. Beside of the influence of mother tongue of Indonesian students, this is also due to the basic level they have not learned about. There are also those who are at advance level but still make mistakes because they forget the rules of the Mandarin grammar. From 20 Indonesian students, there are 13 students who give wrong answer. 


\section{Omission error of time aspect“着zhe”}

According to 陆俭明 (2011), omission bias refers to the error caused by forgetting or omitting certain elements in a word or sentence. In other words, Indonesian students do not use the words where they should be. The following is the form of Omission, shown in Figure 3.

$$
\begin{aligned}
& \text { 他们在唱...歌呢！ } \\
& \text { a. 了 b. 着 c. 过 d. 了与过 e. 不 }
\end{aligned}
$$

Figure 3. Type question omission error of time aspect“着zhe”

From 20 Indonesian students, there are 9 students who did not choose time aspect “着 zhe" into sentences. This shows that second language learning is influenced by mother tongue (Indonesian). Apart from that, the level that makes mistakes is Indonesian students who are learning Mandarin at basic level. At this level, they have not yet learned the form of grammar and do not understand the rules of the language. Sentence (3) below, is a form of using time aspect “着zhe”.

（3）他们在唱着歌呢! They are singing a song!

\begin{tabular}{cccccc}
\hline 他们Tamen & 在zai & 唱chang & 着zhe & 歌ge & 呢!ne! \\
\hline Mereka & sedang & bernyanyi & sedang & lagu & ya \\
\hline
\end{tabular}

The sentence (3) is correct, but Indonesian students feel that the sentence is wrong. Indonesian students do not use the word "着 zhe" in sentences because in Indonesian there is no form of this acronym. In Mandarin, if the verb is followed by an object, the “着 zhe" time aspect must be placed between the verb and the object. In addition, in front of the verb can also be preceded by the adverb “在zai" and at the end of the sentence closed with particles “呢ne" to indicate that the activity is ongoing. The Mandarin grammar structure formation above is still not well understood by students especially at the basic level, because at this level they have not yet learned about the formations.

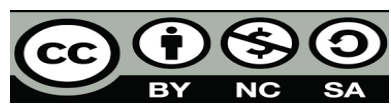




\section{Added error of time aspect“着zhe”}

In Mandarin grammar rules, there are words that do have to be used together with other words, some are not. The rules of use are not yet understood by Indonesian students, especially at the basic level so that errors in the form of additions often occur. The results of questionnaire show that Indonesian students in learning time aspect often do the form of addition error, which should not be added to time aspect “着 zhe", but they do it. From 20 students who worked on this model problem, there were 12 students who made mistakes in the addition error form. Error adding “着 zhe" is seen in Figure 4.

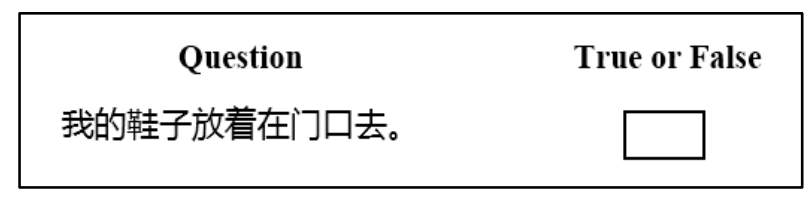

Figure 4. Type question added error of time aspect“着zhe”

The sentence here does not need a time aspect “着zhe" because “放put" and “在in/at" are hard to separate and must be put together. “在at" means that the action has taken place for a short time or is in progress, and there is no need to add an aspect particle “着zhe”. Although the aspect particle “着zhe” indicates the duration of the action and the sentence above is not the grammatical point at all, it is unnecessary to use time aspect “着zhe”. Sentence (4) shows a wrong sentence, which does not conform to the time aspect rules “着 zhe”. 
(4). *我的鞋子放着在门口去。

\begin{tabular}{lcccc}
\hline 我的鞋子wo de xiezi & 放fang & 着zhe & 在zai & 门口去・men kou qu. \\
\hline sepatuku & diletakkan & sedang & di & depan pintu \\
\hline
\end{tabular}

Below is an example of a real problem that is not complicated if the rules of using time aspects are understood. Figure 5 shows that Indonesian students don't understand time aspect “着zhe” well enough. There are many Indonesian students still don't know the grammar rules of the time aspect “着zhe”.

\begin{tabular}{|c|c|c|c|c|}
\hline \multicolumn{5}{|c|}{ 我弟弟今天晚上一直都玩儿 ……游戏。 } \\
\hline a. 了 & b. 着 & c. 过 & d. 了与过 & e. 不用加 \\
\hline
\end{tabular}

Figure 5. Type question added error of time aspect“着zhe”

From the results of questionnaire distributed, there were 10 students who answered incorrectly. Time aspect cannot match the word "一直 yizhi" because the word means continuously, while time aspect “着 zhe" means an event or activity that is taking place. So, it can be seen that the time that is taking place continuously cannot match with the events or activities that are taking place at a time. Sentence (5) shows Indonesian students use the time aspect “着 zhe" instead of word “一直yizhi” . As a result, there have been a lot of errors.

(5). *我弟弟今天晚上一直都玩儿着游戏。*My brother has been playing games tonight.

\begin{tabular}{|c|c|c|c|c|c|c|c|}
\hline $\begin{array}{l}\text { 我弟弟wo } \\
\text { didi }\end{array}$ & $\begin{array}{l}\text { 今天 } \\
\text { jintian }\end{array}$ & $\begin{array}{l}\text { 晚上 } \\
\text { wanshang }\end{array}$ & 一直 yizhi & 都 dou & $\begin{array}{l}\text { 玩儿 } \\
\text { wanr }\end{array}$ & 着 zhe & $\begin{array}{l}\text { 游戏。 } \\
\text { youxi }\end{array}$ \\
\hline $\begin{array}{l}\text { Adik } \\
\text { lelakiku }\end{array}$ & hari ini & malam & $\begin{array}{l}\text { secara } \\
\text { terus } \\
\text { menerus }\end{array}$ & seluruh & bermain & sedang & games \\
\hline
\end{tabular}




\section{Short conclusions}

The most common type of errors is "misuse" type, which also shows high precentage about $65 \%$. The second type is "misordering" has $60 \%$ error. The third type is "added" has $55 \%$ error and the last type is "omission" has $45 \%$ error. The author thinks that "misuse" has a high error rate, because the sentence of type "misuse" can be used in Indonesian. So its influenced by mother tongue. The second is "misordering" because the sentence has two verbs with object, but one of that is not an acronym. Actually Indonesian students understand the rules of using acronym, that if acronym meets with time aspect “着 zhe”, the time aspect “着 zhe” must be placed between the acronym word. But the placement of the word is wrong. They think “玩儿 手机 wanr shouji” is the word of acronym, but it's not. So, this is what causes misordering, which is the lack of understanding of what words are included in the acronym word. The third is type errors of "added". In this type there are two questions. From these two questions, the writer averaged then concluded that there were 55\% of Indonesian students who answered incorrectly because they still did not understand the rules of time aspect “着 zhe" time aspect. It means that they did not yet know when and with what time aspect “着zhe" could match. The last form is "omission". There are still some Indonesian students who did not understand or have not learned from the rules of using the time aspect, which causes an error in answering the question.

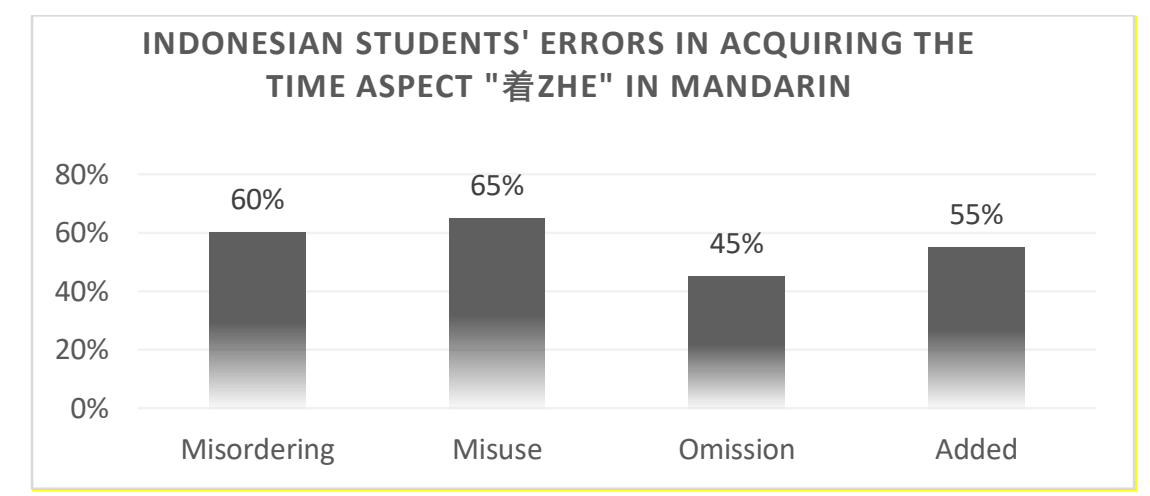

Figure 6. Indonesian students' errors in acquiring the time aspect “着zhe” in Mandarin 


\section{The strategy of teaching method:}

\section{a. Step by step}

Students who learn a grammatical point, must pay attention to a certain order. When learning Mandarin time aspect "着zhe", teachers should first explain the basic of pragmatic rules gradually step by step. For example, time aspect "着zhe" have several rules. The most basic rule is that time aspect should be placed after the verb. When the verb is a conjunction, the tense should be placed between the verbs. For example: "他们在唱着歌呢 tamen zai chang zhe ge ne". Knowing these rules can reduce the bias of Indonesian students. The teaching of tense words should run through the entire Mandarin time aspect "着zhe" learning process step by step. Once you find a mistake, then tell the student about it.

b. Perseverance in study and practice

It is difficult for foreign students to learn Mandarin, and there are not so many explanations about Mandarin time aspect "着zhe" in Mandarin textbooks. When Indonesian students have just started to learn Mandarin, they only know the basic rules of Mandarin time aspect that is, Mandarin time aspect "着 zhe" should be placed after the verb. Therefore, Indonesian students must study perseverance of the grammatical point of Mandarin time aspect “着zhe”, and perseverance in practice questions about time aspect “着zhe”.

\section{CONCLUSION}

Time aspect Mandarin “着 zhe” is a form of Mandarin grammar that is often used. This time aspect “着 zhe” has several rules in matching with other words. To understand this, Indonesian students need to learn step by step and perseverance in study and practice, so they can understand the uses of time aspect “着 zhe”. If the rules of the time aspect “着 zhe” are not understood, they will cause performance errors. There are four mistakes performance often done by Indonesian students. The highest form of performance error is misuse about $65 \%$, then the form of misordering errors, about $60 \%$, then the form of error is added around $55 \%$, and the last is $45 \%$ omission error. This happens

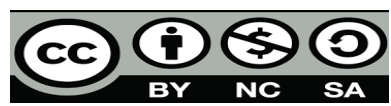


because Indonesian students did not understand or forget the rules of the time aspect, so they use Indonesian grammar in using the time aspect of “着 zhe”.

\section{ACKNOWLEDGEMENT}

Thank you for the correspondent who studied in Nanchang University, China that gives us that fill our questionnaire about the uses of time aspect “着zhe". Thank you also for the lecturer of Nanchang University that help us to conduct this research.

\section{ABOUT THE AUTHORS}

1. Elvira Septevany is a lecturer at tourism department in Politeknik Negeri Bali. In 2018, she is teaching basic Mandarin and tourism Mandarin. By 2011, she finished her bachelor from Hasanuddin University, major English Literature. In 2018, she got her master degree from Nanchang University, major linguistics and applied linguistics.

2. Liu Dandan is a Ph.D candidate in linguistics, faculty of arts, Udayana University. By 2006, she finished her Bachelor Degree from Zhengzhou University, major in Chinese Language and Culture. In 2010, she got her Master Degree from the same university, major in Comparative Literature and World Literature. At the same year, she studied Master again in Hasannuddin University, majoring Indonesian Language and Literature, and finished by 2015. After that, she continued to Doctoral study program of Linguistics in Udayana University, Denpasar, Indonesia. As a Chinese language teacher, she has been worked in the Confucius Institute at Hasanuddin University for seven years.

3. Ria Rizki Marsuki is a lecturer at study program of pendidikan bahasa mandarin in Universitas Negeri Semarang. In 2019, she is teaching Chinese. By 2013, she finished her bachelor degree from Hasanuddin University, major Japanese Literature. In 2017, she finished her master degree from Nanchang University, major Teaching Chinese to Speakers of Other Languages. 


\section{REFERENCES}

[1] 陈德铭. (2011). 印度尼西亚学生学习汉语时态词“着、了、过”的偏误分析. China: Huadong Normal University.

[2] 房玉清. (1992). 时态词“了”“着”“过”的语义特征及其用法比较. 汉语学习, 1, 14-20.

[3] 刘催勤. (2006). 印尼学生时态词习得研究. China: Jinan University.

[4] 陆俭明. (2011). 现代汉语语法答问 (上) Questions and answers on modern Chinese grammar 1. China: Peking University Press.

[5] 吕圆. (2012). 印尼、泰国、韩国留学生时态词“着”习得研究. China: Hunan University.

[6] 穆颖. (2001). “着、了、过”当为动词词尾. 辽宁师专学报 (社会科学版) Journal of Liaoning Teachers College (Sosial Sciences Edition), 4(4), 37-38.

[7] July Dianita Tarigan. (2016). Penggunaan kalimat aspek bahasa Mandarin dengan bahasa Indonesia (analisis kontrastif) 汉语和印尼语动作的状态对比分析. Medan: Universitas Sumatra Utara.

[8] Indihadi, Dian. Analisis Kesalahan Berbahasa. Bandung: Universitas Pendidikan Indonesia.

[9] Mansur Akil. (2009) Aspek, adverbial waktu, dan kala dalam bahasa Inggris dan bahasa Indonesia. Sawerigading, 15(3), 329-335.

[10] Rika Ariandini Hutasoit. (2012). 汉语时态词“了”和“过”在句子中的应用. Medan: Universitas Sumatra Utara

[11] Yi Ying. (2011). Perbandingan karakteristik dan fungsi kata keterangan bahasa mandarin dan bahasa Indonesia. Humaniora, 2(2), 944-949. 